\title{
Technological change and institutions: a case study
}

Citation for published version (APA):

Parto, S. (2003). Technological change and institutions: a case study. UNU-MERIT, Maastricht Economic and Social Research and Training Centre on Innovation and Technology. MERIT-Infonomics Research Memorandum Series No. 033 https://doi.org/10.26481/umamer.2003033

Document status and date:

Published: 01/01/2003

DOI:

10.26481/umamer.2003033

Document Version:

Publisher's PDF, also known as Version of record

\section{Please check the document version of this publication:}

- A submitted manuscript is the version of the article upon submission and before peer-review. There can be important differences between the submitted version and the official published version of record.

People interested in the research are advised to contact the author for the final version of the publication, or visit the DOI to the publisher's website.

- The final author version and the galley proof are versions of the publication after peer review.

- The final published version features the final layout of the paper including the volume, issue and page numbers.

Link to publication

\footnotetext{
General rights rights.

- You may freely distribute the URL identifying the publication in the public portal. please follow below link for the End User Agreement:

www.umlib.nl/taverne-license

Take down policy

If you believe that this document breaches copyright please contact us at:

repository@maastrichtuniversity.nl

providing details and we will investigate your claim.
}

Copyright and moral rights for the publications made accessible in the public portal are retained by the authors and/or other copyright owners and it is a condition of accessing publications that users recognise and abide by the legal requirements associated with these

- Users may download and print one copy of any publication from the public portal for the purpose of private study or research.

- You may not further distribute the material or use it for any profit-making activity or commercial gain

If the publication is distributed under the terms of Article $25 \mathrm{fa}$ of the Dutch Copyright Act, indicated by the "Taverne" license above, 
MERIT-Infonomics Research Memorandum series

Technological Change and Institutions: A Case Study

Saeed Parto

2003-033

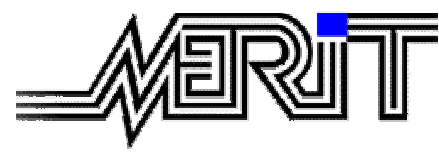

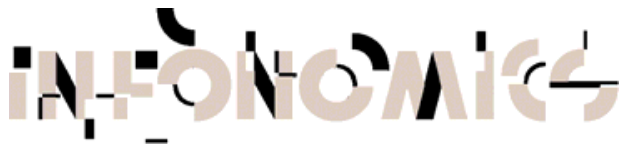

MERIT - Maastricht Economic Research

Institute on Innovation and Technology

International Institute of Infonomics

PO Box 616

6200 MD Maastricht

The Netherlands

$\mathrm{T}:+31433883875$

F: +31433884905

PO Box 616

6200 MD Maastricht

The Netherlands

T: +31433883875

F: +31 453884905

http://uww.merit.unimaas.nl

e-mail:secr-merit@merit.unimaas.nl

http://www.infonomics.nl

e-mail: secr@infonomics.nl 


\title{
Technological Change and Institutions: A CASE Study
}

\author{
Saeed PARTO \\ Maastricht Economic Research Institute on Innovation and Technology \\ (MERIT) \\ University of Maastricht \\ P.O. Box 616, 6200 MD Maastricht \\ The Netherlands \\ Tel: $31(0) 433883352$ \\ Fax: $31(0) 433884905$ \\ s.parto@merit.unimaas.nl
}

\begin{abstract}
The arena of mobile telecommunication in Europe has undergone a technological transition from analogue (first generation) to digital (second generation) technologies. While this transition is immediately attributable to shifts in demand and supply patterns, closer examination reveals that there are numerous other intervening factors that have facilitated this transition. This paper utilizes a conceptual framework for institutional analysis developed in earlier work to identify and discuss some of these factors. The paper concludes with a discussion of the implications from this study for an institutional perspective on technological change.
\end{abstract}

Keywords: Technological Change, Institutions, Institutional Analysis, Policy

\section{Acknowledgements}

I am grateful for the constructive comments of Robin Cowan, Andreas Reinstaller, Rifka Weehuizen, David Doloreux, and the participants at the European Association of Evolutionary Political Economy (EAEPE) conference held in Maastricht, November 7-10, 2003. The usual disclaimers apply. 


\section{Introduction}

By the mid 1990s the Global System for Mobile Telecommunications (GSM) group of technologies had become almost fully established in Europe while making important inroads into other markets. ${ }^{1}$ In 1995 GSM had more than 21 million subscribers in 133 networks operating in more than 105 countries. The daily average for new subscribers in the same year was put at 50,000. Given the historical pattern of dominance in the information and communication technology (ICT) market by the US and Japanese firms, GSM represented a major coup for the European economy as a whole as the main beneficiary. The uptake of GSM was perhaps most notable in Nordic countries and Italy. In 1999 Finland was reported to have 45.6 subscribers per 100 inhabitants, Norway 38.4, Sweden 35.8, Denmark 27.5, Iceland 24, and Italy 20.1. The existence of a large and rapidly growing market for GSM in Nordic countries was matched by the strong performance of Nordic producers of telecommunications equipment who led the production of equipment conforming to GSM standards. Both Ericsson (Sweden) and Nokia (Finland) played quite central roles in developing GSM. Motorola (US) and Siemens (Germany) have maintained a presence while Japanese multinationals represent the third rank of competitors.

Hommen and Mannimen (2003) underline centralized control by the European Commission through setting up the European Telecommunications Standards Institute (ETSI) as one of the main reasons for the success of GSM. The rationale for the Commission's central control is said to have been the realization that instituting a harmonized market would require powers beyond what could be mustered by the traditional (national) public telephone operators and telephone and telegraph operators. The ETSI's mandate was to harmonize the growingly diverse mobile telecommunication market in Europe. Later ETSI also played a central role in providing access to the African, Asian, Australasian, and the Middle Eastern markets for European manufacturers. A notable difference in the approach taken by ETSI to fulfill its mandate was the involvement of both manufacturers and operators in the processes of standard making and regulation of the market.

It is widely accepted that the intervention by the European Commission in the mobile telecommunication market played a central role in facilitating the shift from first

\footnotetext{
${ }^{1}$ This brief history is based on an extensive study conducted by Hommen and Minnenan (2003).
} 
generation analogue technologies to second generation digital technologies. There is, however, insufficient detail on the context within which this transition occurred. Utilizing a conceptual framework for institutional analysis developed in earlier work (Parto 2003) this paper identifies and elaborates on the role of other, perhaps less tangible but nevertheless important, factors that contributed to this transition. The paper concludes with a discussion of the implications from this study for an institutional perspective on technological change. The next section reconceptualizes technological transitions to underline the role of institutions in transitions from one technological regime to the next. The third, fourth, and fifth sections develop the conceptual components of the framework for institutional analysis by making the links between institutions and economic activity (section 3), devising a typology of institutions (section 4), and making the link between learning and socio-economic change from an institutionalist perspective (section 5) while the sixth section applies the framework to the case of GSM. The final section discusses the findings and the implications of the approach adopted in this paper for conducting institutional analysis.

\section{Technological Transitions and Institutions}

Broadly viewed, society is a configuration of norms, forms, rules, and practices and a community of rule followers with distinctive socio-cultural ties and connections. There are in addition inter-subjective understandings based on shared codes of meaning and ways of reasoning, and senses of belonging (Olsen 2000). As an evolutionary change a "transition" (Rotmans, Kemp, and van Asselt 2001), or a fundamental structural change, such that the mode of production or materials flow in the economy is significantly and irreversibly reconstituted, requires persistent external attractors and responsive internal actors over time to mould the new "instituted process" born of a combination and recombination of old and new institutions to generate new forms, rules, and practices to be adhered to by the rule followers.

A technological transition is said to occur when a new (significantly different) dynamic equilibrium is reached (Rotmans et al. 2001). The concept of transition is firmly rooted in the development of complex systems (Nicolis and Prigogine 1989) consistent with which under certain conditions, open systems with a gradient across their boundaries will move away from equilibrium and will establish new stable 
structures (Kay 1994). The development of complex systems is characterized by phases of rapid organization leading to steady states, which after a period of relative calm move toward rapid reorganization to constitute a new steady state. Stability in a dynamic equilibrium is indicated through presence of clearly identifiable structures, routines, and repetitions whose confluence increases the predictability of occurrence of certain future events or activities.

The process of change in a dynamic equilibrium is indicated by weakened structures, breakdown in routines and diminished repetition and predictability. If change-making factors persist and continue to gain strength, structural changes begin to emerge in the subsystem through an accumulation of socio-cultural, economic, ecological, and institutional changes. During this phase of transition there are collective learning processes, social and technical innovations, diffusion, and embedding all leading to a reduction in the speed of change and the institutionalization of new structures, routines, and behaviours - indicating that the subsystem has stabilized and reached a new dynamic equilibrium. The relative stability of the new equilibrium is in part evidenced through changes in and movements among different types of institution. As a result of the newfound stability, new forms of associative institutions such as business networks, or significant changes in the functions of existing networks, begin to emerge; new or modified habits and routines become established at the individual, organizational, and societal levels of inter-relation; significant changes in fundamental values and formal structures can be noted; and, a proliferation of prescriptions and proscriptions enters discourse on how the society as a whole should respond to change. It may thus be concluded changes in any subsystem of the economy can only meaningfully be studied as being embedded in an institutional context. This generalization is qualified in the next section.

\section{Economic Activity and Institutions}

Much of the analysis claiming recognition of the importance of institutions in economic activity does little more than throwing in institutions as an add-on "factor" or a "filter" to be accounted for in schematics representing causal flows in a given situation. A popular tendency is to view institutions as constraints that bear upon a "non-institutional" economy or market, failing to see economies and markets as collections of institutions (Hodgson 1999a: 145). The main characteristic of the 
institution is the "permanency" or "invariability" relative to the individual as a unit of analysis (Hodgson 1988, 1999a). "The institution" is therefore more akin to spatial and temporal inquiry than "the individual" with a fixed set of preferences (Williamson 1994). The focus by some economists on "the institution" represents a significant departure from the standard rational choice theory of neoclassical economics. This renewed focus on institutions underlines the importance of such factors as culture in determining economic actors' operative goals, values, and views of the choice context insofar as actions involve coordination with or will induce responses from other actors (Nelson 1994:130, Jessop 2000).

\section{TABLE 1}

Yet there is a startlingly wide range of definitions and descriptions for "institution" and "institutions", rendering the task of accounting for institutions operationally challenging. There is reasonable unanimity among institutionalists as to the instrumentality of institutions in economic activity, however. Institutions play a functional role in providing a basis for decision-making, expectation, and belief (Hodgson 1988:205). More broadly, institutions "structure" inter-relations: they enable individuals to understand what other individuals are doing, are expected to do, and what may and may not be done. Institutions are "social relations" that frame the activities of production, consumption, and exchange (Setterfield 1993:756); the substance rather than merely the boundaries of social life (Hodgson 1988:134); and the guide to reduce uncertainty in human interactions (North 1990:3-4). As such, institutions operate at and through different arenas that may be grouped into levels of inter-relation, scales of governance, and systems (table 1).

There is broad agreement among institutionalists that as a process the economy is “instituted" (Polanyi 1957) over time through social relations in a co-evolving cultural context. For institutionalists key to understanding the processes of growth and change are the institutions of the economy, as well as individual preferences. But understanding institutions requires appreciation of complexity, continuity, and evolution in historical time. The task requires carefully organized categories that reveal the levels, scales, and systems around and through which institutions are woven (table 1). Institutions define inter-relations at the social, organizational, and societal 
levels; are context-specific and operate at, through, and across different scales of governance; and structure what occurs in social, economic, and political systems.

Context specificity may also manifest itself as path dependency, cumulative causation, and lock-in (Hodgson 1994). Path dependency may be described as “dependence on initial conditions" (after Arthur 1990), or a recurring emergence of initial conditions, resulting in relative permanency (Hodgson 1988, 1993, 1999a) of particular habits / customs and institutional forms. Cumulative causation is closely associated with the better-known economic concept, the "multiplier effect". Cumulative causation is thus defined as the unfolding of events connected with a change in the economy (Myrdal 1957) due to the appearance of a new enterprise which may be private, e.g., a factory, or public, e.g., a government institution or a public-private partnership. Lock-in and its relationship with path dependency and cumulative causation are best captured through the oft-cited case of how the QWERTY keyboard arrangement, despite proven inferiority to other key arrangements, evolved to become the standard in keyboard arrangement.

Scott (2001:48) goes further than most in providing a view of institutions that captures the multi-dimensionality of institutions by describing them as resilient social structures composed of cultured-cognitive, normative, and regulative elements to bring order and stability to social life. In addition, institutions operate at multiple scales of jurisdiction and levels of interpersonal relationships to connote dynamic stability. We may deduce from Scott's (2001) description that institutions collectively act as an integrated web running through different systems (e.g., social, economic), scales of governance (e.g., local, regional, national), and levels of embeddedness (e.g., individuals, organizations, societies). Three additional elements may be added to this mix.

First, long-term institutional change is path dependent and derived from the economy's specific adjustment path toward certain institutions (Setterfield 1993, Hodgson 1999a). Second, institutional evolution is shaped by the feedback process by which human beings perceive and react to changes in their environment, through what North (1993) calls "shared mental models". Third, institutional evolution is the product of the symbiotic relationship between institutions and organizations (North 1990:7) in a process best described as a continuum and denoted as "cause-effect- 
cause". We may also add that institutions are at once persistent, resistant to change, but capable of changing in evolutionary time, and transmitted through various means to consecutive generations to provide a certain degree of continuity, stability, predictability, and security. Because institutions are manifest in all spheres of socioeconomic life, and by most accounts play important roles in facilitating and curtailing change, there is a need for meaningful categorization so as to make analysis of institutions possible where they are manifest and not as a grey box appearing in schematics of socio-economic change. In the next section a typology of institutions is presented to allow such categorization.

\section{A Typology of Institutions}

Given this "key variable" status of institutions in economic analysis it is crucial that the properties of the variable, and the role(s) expected of it, are defined and articulated. This of course is no simple task. What is presented in the next few sections is far from the final word on institutions and institutional analysis. It is rather an attempt to bring structure and a common language to a fundamental yet poorly defined aspect of socio-economic enquiry. In the next section five "types" of institution are identified to provide a loose but necessary structure for institutional analysis. The typology is used in subsequent sections to examine technological change in the European Global System for Mobile Telecommunication industry. Particular emphasis is placed on the role of institutions in technological "transitions".

Institutions are made up of symbolic elements, social activities, and material resources (Scott 2001) to define the structure for interactions among humans based on rules, norms, and values. Institutions may appear as organizations, cultural phenomena, or structures sharing important commonalities as depicted in table 2. All institutions may be viewed variously as production systems, enabling structures, social programmes, or performance scripts depicting stable designs for chronically repeated activity sequences (Jepperson 1991:144-5). As such, institutions are produced, modified, and/or reproduced by human behaviour (Scott 2001). The "permanency" or durability of institutions is only relative as institutions continuously undergo change due to societal dynamics and entropy, or a tendency toward disorder or disorganization (Zucker 1988:26) and a subsequent reorganization to produce new or modified institutions. To illustrate, an associative institution can transform, 
overtime and under certain circumstances, into a regulative or constitutive institution if it is able to reinvent or reposition itself in response to changes and opportunities in the total system. According to the typology in table 2, such transformation redefines the roles of the institution and makes the institution a more integrated and stable part of the socio-economy.

Table 2 expands on Scott's (2001:48) "pillars” of institutions to introduce five types of institution. Grouping institutions in the manner indicated in table 2 can provide clues on how institutions are manifested at different levels, systems, and scales. The right hand column provides descriptions and examples of these institution types. Institution may be "associative", in that they comprise socio-political structures characterized by exclusion, socialization, controlling conditions of incumbency, and hero worship to express certain values or interests. Associative institutions are reproduced by succeeding generations of power holders to exercise a degree of selectivity. ${ }^{2}$ Second, institutions may be "behavioural" in that they are transmitted by various carriers, including symbolic and relational systems, routines, and artefacts. ${ }^{3}$ Third, institutions may be "cognitive" in that they are based on values and embedded in culture. ${ }^{4}$ Fourth, institutions may be "regulative" in that they provide stability and give meaning to social life. ${ }^{5}$ Fifth, institutions may be "constitutive" in that they are social structures that have attained a high degree of resilience and operate at multiple scales of jurisdiction. ${ }^{6}$

\section{TABLE 2}

There are in addition numerous "hybrid" descriptions of institutions consisting of two or more of the types identified in table 2. For example, Setterfield (1993:761) defines institutions as "exogenous constraints" (regulative) which in time become endogenous to the working of the economy and the actions of individuals (behavioural). Scott (2001:52) also refers to institutions as "regulatory processes" to establish rules, inspect others' conformity to them, and as necessary, manipulate sanctions. The

\footnotetext{
${ }^{2}$ Based on Stinchcombe (1968:107-111). See also Parsons (1940:190) and Scott (2001:55).

${ }^{3}$ See Durkheim (1950), Mitchell (1950:373), Neale (1994:404), and Veblen (1919:239).

${ }^{4}$ See Douglas (1982:12), Neale (1987:1184), and Scott (2001:57-58).

${ }^{5}$ See Bush (1986), Elster (1989), Hayden (1993:309), Hodgson (1988:205), Hughes (1939:297), North (1990:4), Parsons (1990:327), Rutherford (1994:182), Scott (2001:34,50-54), Setterfield (1993:756,761), Thelen and Steinmo (1992:2), and Tool (1993:132).

${ }^{6}$ See Commons (1924), Cooley (1956), Giddens (1984:13), Hodgson (1988:134,153), Neale (1987:1180, 1994:404), North (1990:3-4,28,61,69), Scott $(2001: 75,95)$.
} 
internalization of various institutions by individuals and groups of individuals can be cause for inertia or resistance to change. Hughes (1939) viewed institutions as behavioural and regulative in that they determine individual or group action according to a set of mores and/or formal rules. Similar views are expressed by Neale (1987) and Hayden (1993). According to Rutherford (1994:182) institutions are at once regulative and constitutive in that they denote regularity in behaviour by individuals at large and by individuals within an organization. An organization is in turn subjected to external (social) regularities which are constituted at higher scales of governance. ${ }^{7}$

Conducting institutional analysis in the manner implied in table 2 requires specification of the level(s), scale(s), and the system(s) through which institutions are being studied. For example, phenomena at the national scale of governance occur in relation to factors at higher and lower scales. Institutional analysis of a national phenomenon would recognize but not conduct in-depth analysis of the local or continental scales. Taking a multi-level, multi-system, and multi-scale perspective on institutions as suggested here increases the need for the articulation of the research question and of the analytical approach adopted. Articulation and specification enable us to go beyond merely describing institutions collectively as an important factor to consider. This articulation further allows research to focus on the key institutions in a given situation and avoids "analysis-paralysis" that may result from being overly concerned with the importance of complexity and the need to remain holistic.

The structure suggested in table 2 is best used in conjunction with Neale's (1987) method for identifying through recognition, rather than defining, institutions. Components of institutions are manifested as activities of people in situations and in contexts. Observation and characterization of these components allow operational recognition, not definition, of institutions. There are three characteristics that allow institution identification: "First, there are a number of people doing. Second, there are rules giving the activities repetition, stability, predictable order. Third, there are folkviews - most certainly what Walton Hamilton meant by a 'bundle of intellectual usages' - explaining or justifying the activities and the rules" ${ }^{\prime 8}$ (Neale 1987:1182).

\footnotetext{
${ }^{7}$ For a fuller discussion of institutions see Parto (2003).

8 "Folkviews explain or justify the rules to the people of a society, often explaining and justifying simultaneously. Folkviews include values, but equally they include the ideas that people have about the universe around them - physical, chemical and biological, as well as social; and the mystical and
} 
"Doing" can be seen and thus identified; "rules" can be identified by "ordering the doings into repetitive event sequences"; and the "folkviews justify the activities or explain why they are going on, how they are related, what is important and what is unimportant in the patterns of regularity. Folkviews can be discovered by observation, but here the eye is a minor instrument and the ear is a major one" (Neale 1987:1183).

When we speak of something as being "instituted" we at once allude to something that has been "learned" and adopted by individuals, singly or in groups, which affects inter-relations at all levels; something by which individuals or groups of individuals may be characterized at different scales; and perhaps most importantly, something that reveals a degree of relative permanency as manifested in habits, customs, and so forth within or across systems. Depending on the purpose of the analysis some levels, scales, or systems need to be more, or less, emphasized than others since not everything is equally important in all situations and all the time.

Institutionalization processes are closely associated with processes of learning and unlearning. (Un)Learning entails change of values. The rate at which value change occurs is directly dependent on the belief system in which the specific values reside. Deeply held values are much slower to change, if at all, while tactical values may change rapidly in response to exogenous pressures. Belief system values and learning are discussed in more detail in the next section.

\section{Learning and Belief System Values ${ }^{9}$}

The values that determine the behaviour of economic agents may be grouped under three belief systems. Primary belief system values span within and outside the subsystem and are the most difficult to change. Examples include religious or ethnic beliefs on fundamental issues such as human domination over nature or equity and equality. Secondary values are subsystem specific and concern the strategies for addressing a shared problem. Secondary values may be expressed as ideological positions on strategy and policy instruments, e.g., government regulation versus voluntary self-regulation, to address a shared problem. Tertiary values are associated with the technical and administrative parts of the subsystem that hosting the problem.

transcendent as well as the worldly... [Folkviews] also include all the organizing and directing ideas of a culture or subculture" (Neale 1994:403)

${ }^{9}$ This section has benefited from various exchanges with Andreas Reinstaller. 
That is, tertiary values are concerned with how strategies are implemented. As such tertiary values are continually tested, debated, and thus prone to change more easily and frequently than primary and secondary belief system values. ${ }^{10}$ Changes in the primary, secondary, and tertiary values are directly traceable to changes in different types of institution as defined in table 2 .

To illustrate, knowledge accumulated through the trials and errors of policy implementation to address groundwater contamination continually presents the subsystem actors, i.e., those concerned and willing to take action on groundwater contamination, with opportunities to learn, debate, and potentially change opinions. A change of approach in policy implementation based on new learning represents a tertiary value change and may affect secondary values. The secondary values may change in response to learning that self-regulation by industry to protect groundwater does not in fact work and is prone to abuse by free-riders, for example. A change in the secondary values within the subsystem may be to agree to constrain waterpolluting activities through legislation. Such a constraint does not question the supremacy of the market or put environmental protection before economic gain. Over sufficiently long periods of time and accompanied with technological advances, secondary value changes could be reversed in light of new information and raise questions about deeply held beliefs (primary values) such as the legitimacy of human domination over the natural environment.

The primary belief system values are closely associated with constitutive institutions, but also find expression in regulative, cognitive, behavioural, and associative institutions. The primary values form the basis for understanding and interpreting the states of the world. The process of understanding is a process of evaluation based on the fundamental axioms of socio-economic life as determined by such constitutive institutions as language or property rights, defining and setting the boundaries of social relations at different levels. The boundaries of social relation are established through routines and norms as behavioural institutions. The values attached to specific states of the world are identified and turned into constraints and guidelines of thought,

\footnotetext{
${ }^{10}$ Primary, secondary, and tertiary belief system values are almost identical to Sabatier and JenkinsSmith's (1999) “deep core", "policy core”, and "secondary aspects", respectively. The definitions used here also draw on Ostrom's (1999) "rules" (mutually understood shared prescriptions on must, must not, and may), "norms" (mutually enforced shared prescriptions), and "strategies" (regularized plans by individuals within the structure of incentives produced by rules, norms, and expectations of others).
} 
becoming manifest as secondary belief system values as reflected in regulative institutions, e.g., rules and regulations, and cognitive institutions, e.g., cultural and social values. Secondary values determine the basic strategies for choosing, assembling, or modifying operative routines and generate tertiary values that decide which technical or administrative tools are selected for the operationalizaton of selected strategies.

A transition to a new technological regime is intimately linked with processes of learning / "unlearning" and the associated institutional change. In the case of the European mobile telecommunication subsystem the task then is to establish i) what changes over time and in which primary, secondary, and tertiary values preceded the shifts in the technological regime, and ii) how the changes in the primary, secondary, and tertiary belief system values were reflected in institutional change as manifested and traced in the typology of institutions in table 2.

\section{Case Study: Adoption of the Global System for Mobile Telecommunication (GSM) ${ }^{11}$}

Until the early 1980s the mobile telecommunication arena could be best described as a diverse arena consisting of numerous first generation telecommunication technologies and operators. This diversity limited international roaming and caused fragmentation in the equipment market. There was general recognition that the potential growth of the market could only be realized through higher degrees of coordination and standardization both in manufacturing technologies and telecommunication protocols. In 1982 Conférence Européenne des Administrations des Postes et Télécommunications (CEPT) formed a group with a mandate to devise mobile telecommunication standards. Perhaps due to the rapid growth of the market the European Commission became increasingly interested and moved to assume a more central position in the evolving arena.

The Commission established the European Telecommunications Standards Institute (ETSI) which by 1996 assumed all the functions of the group formed by CEPT. A Memorandum of Understanding drafted by the CEPT-appointed group in 1987 and

\footnotetext{
${ }^{11}$ The section is largely a re-interpretation of the historical account and analysis provided in Hommen and Manninen (2003).
} 
signed by 13 countries had been signed in 1996 by 167 regulators and operators from 103 European and non-European countries. The migration of control over the process to institute a Global System for Mobile Telecommunications (GSM) from CEPT to ETSI was in effect a move upward in the scale of governance from national to continental and downward from national regulation to a negotiative framework involving operators, manufacturers, user groups, and research bodies to devise new all encompassing standards for mobile telecommunications. A direct outcome of the hand-over was the new authority by ETSI to create a whole family of compatible technological standards and pave the way for the advance and consolidation of GSM's rapid domination of the European market. The failure of contending technologies such as D-AMPS and CDMA, both digital, to become established in Europe is largely related to the partitioning of the European market by ETSI through its family of standards. This partitioning contrasted with the segmented North American market which had not created a central regulatory / standard setting body such as ETSI but had relied instead on "voluntary" standards (table 3).

\section{TABLE 3}

The centralized authority of ETSI, formalized in the late 1980s to set standards for mobile telecommunication was accompanied with increased competition in the market due to liberalization, set in motion with the EC Green Paper (1987), and rapid advances in digital technology. The Green Paper also called for strong and concerted effort in the development of telecommunications standards for the internal market. These developments undermined a stable regime based on analogue communication technology to pave the way for transition to a new regime based on (GSM) digital technology. The new regime involved a greater number of actors and a much greater complexity in the relations among them. Private firms were now competing directly on an international market and faced greater risks and opportunities that necessitated forming strategic alliances with other firms and public actors such as universities and research institutes to bolster critical mass and knowledge base.

ETSI's creation is said to have been motivated by a concern about Europe's competitiveness in telecommunications in light of the threat posed by US multinationals (Dang-Nguyen et al 1993). ETSI collaborated with equivalent US and Japanese standard setting counterparts to devise comparable standards and adopted an 
open door policy insofar as interested parties within the EU were concerned. The membership consisted of national communications and postal service providers and manufacturers, public research organizations and new entrants into the mobile telecommunication service provision market. ETSI also emphasized extensive public enquiry and instituted rules and procedures for resolving disputes on such issues as roaming charges and intellectual property rights. Arguably, ETSI's success in instituting GSM is attributable to a problem, i.e., threat of competition by US multinationals to "corner" the European market in a new technological environment, a policy of liberalization accompanied with centralized coordination and standards setting activities, and the political commitment to nurturing cohesion among the national economies of member states. The confluence of the problem, policy, and politics streams (Kingdon 1984) combined with a shift in the demand and supply patterns created a perhaps non-replicable window of opportunity to balance coordination / standardization with competition.

In examining the statistics in table 3 the following observations can be made. First, without a doubt the global market for second generation mobile telecommunication technology has been fragmented with Europe and Africa being almost dominated by the GSM group of technologies. This may be due to the scale of governance at which attempts were made toward standardization and a transition to the second generation technological regime. Second, the expansion of the market in Europe for GSM related technologies was due to "spontaneous" shifts in the demand and supply patterns. Third, the segmentation occurred due to the confluence of a problem, politics, and policy to exploit a window of opportunity (proactively or reactively) through new forms and governance mechanisms. Fourth, there was covert planning by EU governments to keep out the competition while advocating market liberalization.

On closer examination it appears that the demand and supply patterns did indeed shift, but not entirely spontaneously as numerous other, inter-related, factors were involved:

- The EU took a determined step to induce the shifts in demand and supply in this sector because it believed in digital technology as a potential source of competitiveness that could kick-start the European economies, create jobs, and so forth. 
- Measures taken for this inducement included taking over the functions of CEPT by instituting ETSI, increased diversity of actors involved in the standard setting process (operators, manufacturers, user groups, and research bodies).

- An explicit goal for ETSI was to increase subscription rates within the EU and market penetration rates where they were lower than average. Demand was indeed induced through standardization and regulation to facilitate market penetration and increased subscription. But key is the role played by private actors, e.g., Ericsson, Nokia, in devising the new standards and regulations in collaboration with national and EU government agencies.

- Because of this collaborative environment it was relatively easy for the private actors to communicate their structural needs, e.g. more computer science graduates and R\&D knowledge from various sources, to the policy makers. One direct result of this arrangement was a relaxation of strict IPR laws through an obligatory licencing system.

- Increased demand was matched in a timely fashion by private actors possibly because private actors were involved in inducing the demand for GSM in the first place.

Certainly, these developments acted as, or led to the emergence of, catalysts that initiated a series of institutionalization processes. Using the typology in table 2 these catalysts maybe grouped according to the type of institution as the likely outcome of the institutionalization process initiated:

- Associative Institutions: some business networks adjusted their functions to a new or emerging environment while other networks emerged to address new needs. Notable associative institutions included strategic alliances among private (and public-private) interests and the formation of CEPT (initiated by operators).

- Behavioural Institutions: Owning a mobile phone became "necessary" due to convenience, limited access to far fewer public telephone boxes, and "hipness" of owning one.

- Cognitive Institutions: Awareness campaigns, advertising

- Regulative Institutions: Legislation, mediation between private and public interests (leading to standards and MoUs) 
- Constitutive Institutions: The formation of ETSI as an evolution of CEPT, generation of standards and the Memorandum of Understanding.

The evolution of GSM suggests that policy learning at higher scales often defines and determines the policy direction while implementation necessitates learning at the firm level accompanied with concurrent processes of institutionalization. The rate at which supra-local forms and routines based on new learning succeed in replacing or modifying local forms and routines is in part dependent on the collective strength at the local scale to contest, or embrace, the externally imposed forms and routines. Initiating the process of transition requires top-down regulation through a combination of coercion and sanction aimed at instituting new forms and routines, buy-in, and cooperation from the actors of the subsystem. Such cooperation often needs to be nurtured and developed from higher scales and based on increased trust in inter-relations among actors over relatively long periods of time. The fact that the subscription levels and market penetration were particularly high in some countries may indeed be largely due to context specificity: Nordic countries have longestablished "negotiated" economies where the historical tendency has been toward relative social peace and institutionalized class co-operation (Jessop 1997: 113) through making compromises.

The key to the success of the negotiated economies has been the ability of the national states to combine orthodox corporatism (involving business associations, trade unions, and the national state) and a "model of concertation" involving "a wide range of extra-economic as well as economic forces... [consisting of] rural and urban petty bourgeois sectors, the local state and functional domains such as health, education, welfare and scientific research" (Jessop 1997: 113, 114-5). Negotiated economies are noted for their ability to bring together, and maintain over time, private and public interests in collaborative arrangements. One could speculate that the collaborative environment of the Nordic EU member states may have (inadvertently) served as a laboratory for the EU government agencies to experiment with establishing a technological niche in an emerging market. However, a more concrete and empirically valid argument about how and why the GSM group of technologies became dominant in Europe would have to be based on a research that pays particular attention to the institutions, as well as the agents, of economic change. 


\section{Conclusion}

This paper has attempted to examine the transition from an analogue (first generation) to a digital (second generation) telecommunication technological regime in Europe in an institutional context. A conceptual framework was devised to account for the collective role of institutions in facilitating this transition while some key events were underlined as catalysts for the emergence of new institutions. The simultaneous learning and unlearning processes associated with this transition were found to be most pronounced at the firm and policy levels. ${ }^{12}$

However, the analysis of the secondary data also reveals that (un)learning does not occur in a vacuum but is a process initiated by a window of opportunity resulting from a confluence of a widely recognized problem (threat of competition), political convictions (for a cohesive European Community and a liberalized European market), policies (to pursue cohesion and competitiveness), and most importantly an evolutionary shift in the demand and supply patterns. Early in the learning process that ensued after this confluence was the realization that the knowledge base could be, and had to be, significantly enriched by involving a diverse group of actors to devise the new standards for mobile telecommunication. Public research organizations and major telecommunication equipment firms began to play central roles in ETSI while key actors like Ericsson began a process of competence building through corporate restructuring, mergers and acquisitions, joint ventures, significant increases in research and development, and upgrading internal skills base.

Institutional analysis of the evolution of particular domains or subsystems needs to accomplish three main tasks. First, the analysis must be aimed at understanding "why" phenomena occurred. Specifically, the enquiry must be "what type of institution, through what scale(s) of governance, and operating at what level(s) of inter-relation are responsible for the observed change"? Second, the analysis needs to identify the causal relationships between some of the main catalysts, and the institutionalization processes initiated by them to contextualize the emergence of new or modified institution types (table 2). Third, for policy purposes the analysis needs to establish the controllability of the catalysts and determine which can be manipulated and which is independent. The analysis should also reveal the institutionalization

\footnotetext{
${ }^{12}$ This conclusion is based on a review of the secondary data in Hommen and Manninen (2003).
} 
processes that may be initiated through intervention to complement, i.e., soften the full effect or boost, independent processes.

An institutionalist approach to policy making is agenda based (Hayden 1993) and should first establish what institutions there are and how they are inter-related. The approach also needs to establish whether the missing institutions or inter-relations could be realistically compensated for, all things considered. The information gathered through this exercise could then be used to (attempt to) facilitate change in an overt manner toward universally legitimate goals such as establishing desirable technologies, fighting global warming, or striving for sustainability in the broadest sense. 
Table 1. Institutional Arenas

\begin{tabular}{|c|c|}
\hline $\begin{array}{c}\text { Levels of } \\
\text { inter-relation }\end{array}$ & $\begin{array}{l}\text { Individual: Among individuals at large based on interpersonal } \\
\text { interdependence where many actors are involved. } \\
\text { Organizational: Within organizations to secure internal cohesion and } \\
\text { among organizations to maximize adaptability of individual organizations } \\
\text { so as to make compatible respective operational unities and independence } \\
\text { with de facto material and social interdependence on other organizations. } \\
\text { Societal: Among operationally autonomous (or closed) functional systems } \\
\text { each with its own autopoietic }{ }^{* * *} \text { codes, programmes, institutional logics and } \\
\text { interests in self-reproduction. }\end{array}$ \\
\hline $\begin{array}{c}\text { Scales of } \\
\text { governance }^{* *}\end{array}$ & $\begin{array}{l}\text { Local (subnational), national, international (between nationally constituted, } \\
\text { functionally differentiated institutional orders), transnational (passing } \\
\text { through national boundaries), and global (covering the globe as a whole). }\end{array}$ \\
\hline Systems & $\begin{array}{l}\text { The whole (Earth-based) system consists of numerous subsystems such as } \\
\text { social, economic, political, and ecological. Subsystems may be composite } \\
\text { and made up parts from two or more subsystems. }\end{array}$ \\
\hline \multicolumn{2}{|c|}{$\begin{array}{l}\text { Adapted from Jessop (1997) } \\
{ }^{* *} \text { Adapted from Mann (1996) and Jessop (1997) } \\
\text { Jessop (1997:102) defines "autopoiesis" as a condition of radical autonomy secured through self- } \\
\text { organization when a system defines its own boundaries relative to its environment, develops its own } \\
\text { operational code, implements its own programmes, reproduces its own elements in a closed circuit and } \\
\text { obeys its own laws. }\end{array}$} \\
\hline
\end{tabular}


Table 2. Levels, Systems, and Scales of Institutions

\begin{tabular}{|c|c|c|c|c|}
\hline Institution Type & Level & System(s) & Scale & $\begin{array}{l}\text { Examples / } \\
\text { Catalysts }\end{array}$ \\
\hline $\begin{array}{l}\text { Associative: Institutions as } \\
\text { mechanisms facilitating } \\
\text { prescribed or privileged } \\
\text { interaction among different } \\
\text { private and public interests }\end{array}$ & $\begin{array}{l}\text { Inter- and Intra- } \\
\text { Organizational, } \\
\text { Institutional }\end{array}$ & $\begin{array}{l}\text { Economic, } \\
\text { Social Political }\end{array}$ & $\mathrm{All}^{\dagger}$ & $\begin{array}{l}\text { Business Networks; Kinship } \\
\text { Groups; Social Classes; } \\
\text { Associations; Interest } \\
\text { Groups }\end{array}$ \\
\hline $\begin{array}{l}\text { Behavioural: Institutions as } \\
\text { standardized (recognizable) } \\
\text { social habits - manifested in } \\
\text { activities of individuals and } \\
\text { groups as reflections of } \\
\text { social norms }\end{array}$ & Individuals) & $\begin{array}{l}\text { Economic, } \\
\text { Social Cultural }\end{array}$ & $\begin{array}{l}\text { Local, Regional, } \\
\text { National }\end{array}$ & $\begin{array}{l}\text { Habits; Routines; Artefacts; } \\
\text { Ways of Doing Things; } \\
\text { Shared Beliefs; Theories in } \\
\text { Use; "How the Game is } \\
\text { Played" }\end{array}$ \\
\hline $\begin{array}{l}\text { Cognitive: Institutions as } \\
\text { mental models and } \\
\text { constructs or definitions - } \\
\text { manifested primarily in } \\
\text { what society expects of } \\
\text { individuals }\end{array}$ & $\begin{array}{l}\text { Individual, } \\
\text { Societal }\end{array}$ & Social, Cultural & $\begin{array}{l}\text { Local, Regional, } \\
\text { National }^{\neq}\end{array}$ & $\begin{array}{l}\text { Cultural and Social Values; } \\
\text { Superstitions; "Wisdom"; } \\
\text { "How the Game Ought to be } \\
\text { Played" }\end{array}$ \\
\hline $\begin{array}{l}\text { Regulative: Institutions as } \\
\text { prescriptions and } \\
\text { proscriptions }\end{array}$ & $\begin{array}{l}\text { Individual, } \\
\text { Inter- } \\
\text { organizational, } \\
\text { Societal } \\
\end{array}$ & $\begin{array}{l}\text { Economic, } \\
\text { Social, Political }\end{array}$ & $\begin{array}{l}\text { Local, Regional, } \\
\text { National, } \\
\text { Continental }\end{array}$ & $\begin{array}{l}\text { Written and Unwritten } \\
\text { "Rules of the Game"; State } \\
\text { as Rule Maker, Referee, and } \\
\text { Enforcer }\end{array}$ \\
\hline $\begin{array}{l}\text { Constitutive: Institutions } \\
\text { setting the bounds of social } \\
\text { relations }\end{array}$ & $\begin{array}{l}\text { Individual, } \\
\text { Inter- } \\
\text { organizational, } \\
\text { Societal }\end{array}$ & $\begin{array}{l}\text { Economic, } \\
\text { Social, Political }\end{array}$ & $\begin{array}{l}\text { Regional, } \\
\text { National, } \\
\text { Continental, } \\
\text { Global }\end{array}$ & $\begin{array}{l}\text { Collective Actions initiated } \\
\text { by the State Agencies, Firms, } \\
\text { Unions, or Citizens Groups; } \\
\text { Language; Property Rights } \\
\text { Structures; Agreements; } \\
\text { Arrangements; Marriage; } \\
\text { Family }\end{array}$ \\
\hline \multicolumn{5}{|c|}{$\begin{array}{l}\text { Associative institutions are present at all scales from local to global. } \\
\text { isenerally, there is a higher degree of heterogeneity at higher scales. The rationale for including the national scale here } \\
\text { is that individuals in a nation are "regulated" by the same formal rules and political system. } \\
\neq \text { Superstitions and social values, though sometimes shared by other nations, are nevertheless likely to be "diluted" } \\
\text { beyond the national scale. } \\
\text { "\# ne number and influence of institutions are inversely related to scale. }\end{array}$} \\
\hline
\end{tabular}

Adapted from Parto (2003)

Table 3. Market segmentation and second generation mobile telecommunication technologies

\begin{tabular}{|l|c|c|c|c|c|}
\hline Technology & Europe & N. America & L. America & Asia & Africa \\
\hline GSM & $89 \%$ & $4 \%$ & $1 \%$ & $35 \%$ & $88 \%$ \\
\hline D-AMPS & - & $27 \%$ & $39 \%$ & $3 \%$ & - \\
\hline CDMA & - & $9 \%$ & $9 \%$ & $14 \%$ & - \\
\hline Analogue & $11 \%$ & $60 \%$ & $51 \%$ & $48 \%$ & $12 \%$ \\
\hline
\end{tabular}

Source: ITU World Communications Database (2002) 


\section{References}

Arthur, B. (1990). "Positive Feedbacks in the Economy," Scientific American 262 (February): 92-99.

Braugenhardt, S. and J. Kaaman (1991). "Open Network Provision - EGs koncept för öppna telenät", Tele (Swedish ed.) 3: 36-40.

Bush, P.D. (1986). "On the Concept of Ceremonial Encapsulation". "The Review of Institutional Thought 3. (December), pp. 25-45.

Commons, J.R. (1924). The Legal Foundations of Capitalism (New York: Macmillan)

Cooley, C.H. ([1902] 1956). Social Organization (Glencoe IL: Free Press)

Dang-Nguyen, G., V. Schneider and R.Werle (1993). "Corporate Actor Networks in European Policy-Making: Harmonizing telecommunication policy" (Cologne: Max Planck Institut fur Gesellschaftsforschung)

Douglas, M. (1982). “The Effects of Modernization on Religious Change”, Daedalus (Winter): 1-19

Durkheim, É. ([1901] 1950). The Rules of Sociological Method (Glencoe. IL: Free Press).

Elster, J. (1989). "Social Norms and Economic Theory." Journal of Economic Perspectives 3 (fall): 99-117.

Giddens, A. (1984). The Constitutions of Society: Outline of the Theory of Structuration (Cambridge: Polity Press).

Hayden, F.G. (1993). "Institutionalist Policymaking”, in Tool, M.R. (ed.) Institutional Economics: Theory, Method, Policy (Norwell, MA: Kluwer Academic Publishers), pp. 283-331.

Hodgson, G.M. (1988). Economics and Institutions: A Manifesto for a Modern Institutional Economics (Cambridge: Polity Press).

Hodgson, G.M. (1993) (ed.). Economics and Institutions. (Aldershot: Edward Elgar Publishing Limited) pp: 51-77.

Hodgson, G. M. (1994). The Return of Institutional Economics. The Handbook of Economic Sociology. N.J. Smelser and R. Swedberg (eds.). (Princeton, NJ: Russell Sage Foundation) pp: 58-76.

Hodgson, G. M. (1999). Economics and Eutopia: Why the learning economy is not the end of history. London, Routledge.

Hommen, L. and E. Manninen (2003). "The Global System for Mobile Telecommunications (GSM): Second Generation", in Edquist, C. (ed.) The Internet and Mobile Telecommunications System of Innovation: Developments in Equipment, Access and Content, (Cheltenham, UK: Edward Elgar Publishing), pages 71-128.

Hughes, E.C. (1939). "Institutions". In Park, R.E. (ed.), An Outline of the Principles of Sociology. (New York: Barnes and Noble), pp. 281-330

Jessop, B. (1997). "The governance of complexity and the complexity of governance: preliminary remarks on some problems and limits of economic guidance", in Beyond Market and Hierarchy: Interactive Governance and Social Complexity, Amin, A. and J. Hausner (Cheltenham, UK: Edward Elgar), pp. 95-128

Jepperson, R.L. (1991). "Institutions, Institutional Effects, and Institutionalization", in Powell, W.W. and P.J. DiMaggio (eds.), The New Institutionalism in Organizational Analysis (Chicago: University of Chicago Press), pp. 143-63 
Jessop, B. (2000). "Institutional (Re)Turns and the Strategic-Relational Approach", Environment and Planning A, 33, 1213-1235.

Kay, J.J. (1994). "Some notes on: The Ecosystem Approach, Ecosystem and Complex Systems and State of the Environment Reporting" (Waterloo, ON: University of Waterloo).

Mann, M. (1996). "Neither nation-state nor globalism.” Environment and Planning A 28: 1960-1964

Mitchell, W.C. (1950 [1937]). The Backward Art of Spending Money and Other Essays (New York: McGraw-Hill)

Myrdal, G. (1957). Economic Theory and Underdeveloped Regions. London, Duckworth

Neale, W.C. (1987). "Institutions”. Journal of Economic Issues. 21 (3): 1177-1206

Neale, W.C. (1994), in Hodgson, G.M., W.J. Samuels, and M.R. Tool (eds.) The Elgar Companion to Institutional and Evolutionary Economics (Aldershot: Edward Elgar Publishing Limited), pp. 402-406.

Nelson, R.R. (1994). "Evolutionary Theorizing about Economic Change." The Handbook of Economic Sociology. Smelser, H.J. and R. Swedberg. Princeton, NJ, Russell Sage Foundation: 108-136.

Nicolis, G. and I. Prigogine (1989). Exploring Complexity, (New York: W.H. Freeman)

North, D. (1990). Institutions, Institutional Change, and Economic Performance (New York: Cambridge University Press).

North D.C. (1993), "Douglass C. North - Autobiography", available at: [http://www.nobel.se/economics/laureates/1993/north-autobio.html]

Olsen, J.P. (2000). "How, then, does one get there? An Institutionalist Response to Herr Fischer's Vision of a European Federation" ARENA Working Papers WP00/22

Ostrom, E. (1999), "Institutional Rational Choice: An Assessment of the Institutional Analysis", in Sabatier, P.A. (ed.) Theories of the Policy Process (Boulder CO: Westview Press), pp. 35-73

Parsons, T. (1940). "The Motivation of Economic Activities", Canadian Journal of Economics and Political Science 6: pp. 187-203.

Parto, S. (2003). "Economic Activity and Institutions: Taking Stock”, MERIT-Infonomics Research Memorandum Series (2003-007).

Polanyi, K. (1957). "The Economy as Instituted Process", in Polanyi, K., C.M. Arensberg, and H.W. Pearson (eds.). Trade and Market in the Early Empires (Chicago: Henry Regnery)

Rotmans, J., R. Kemp, and M. van Asselt (2001). "More evolution than revolution: Transition management in public policy." Journal of Futures Studies, Strategic Thinking and Policy. 3:15-31

Rutherford, M. (1994). Institutions in Economics (Cambridge: Cambridge University Press).

Sabatier, P.A. and H.C. Jenkins-Smith (1999). Frameworks Focusing on Policy Change over Fairly Long Periods", in Sabatier, P.A. (ed.), Theories of the Policy Process. (Boulder CO: Westview Press).

Scott, W.R. (2001). Institutions and Organizations, $2^{\text {nd }}$ edition, (London: Sage Publications).

Setterfield, M. (1993). “A Model of Institutional Hysteresis”. Journal of Economic Issues 27(3): 755-75 
Stinchcombe, A.L. (1968). Constructing Social Theories. (Chicago: University of Chicago Press).

Thelen K. and S. Steinmo (1992). "Historical Institutionalism in Comparative Politics", in Steinmo, S. K. Thelen, and F. Longstreth (eds.), Structuring Politics: Historical Institutionalism in Comparative Analysis (Cambridge: Cambridge University Press).

Tool, M.R. (1993). "The Theory of Instrumental Value: Extensions, Clarifications", in Tool, M.R. (ed.) Institutional Economics: Theory, Method, Policy (Boston: Kluwer Academic Publishers), pp.119-159.

Veblen, T.B. (1919). The Place of Science in Modern Civilization and Other Essays (New York: Huebsch).

Williamson, O. E. (1994). Transaction Cost Economics and Organization Theory. The Handbook of Economic Sociology. N.J. Smelser and R. Swedberg (eds.) (Princeton, NJ. Russell Sage Foundation), pp. 59-77.

Zucker, L.G. (1988). "Where Do Institutional Patterns Come From? Organizations as Actors in Social Systems". In Zucker, L.G. (ed.) Institutional Patterns and Organizations: Culture and Environment (Cambridge, MA: Ballinger), pp. 23-49. 